\title{
Glochiflavanosides A-D: Flavanol Glucosides from the Leaves of Glochidion zeylanicum (GAERTN) A. Juss
}

\author{
Hhideaki Otsuka, ${ }^{*, a}$ Eiji Hirata, ${ }^{b}$ Takakazu Shinzato, ${ }^{c}$ and Yoshio TakedA ${ }^{d}$ \\ Institute of Pharmaceutical Sciences, Hiroshima University Faculty of Medicine, ${ }^{a}$ 1-2-3 Kasumi, Minami-ku, Hiroshima \\ 734-8551, Japan, Faculty of Agriculture, University of the Ryukyus, ${ }^{b} 1$ Senbaru, Nishihara-cho, Nakagami-gun, Okinawa \\ 903-0314, Japan, University Forest, Faculty of Agriculture, University of the Ryukyus, ${ }^{c} 685$ Yona, Kunigami-son, \\ Kunigami-gun, Okinawa 905-1427, Japan, and Faculty of Integrated Arts and Sciences, The University of Tokushima, ${ }^{d}$ \\ 1 Minamijosanjima-cho, Tokushima 770-8502, Japan. Received January 17, 2001; accepted March 10, 2001
}

From the leaves of Glochidion zeylanicum collected in Okinawa, four flavanol glucosides, named as glochiflavanosides $A-D$ were isolated along with known flavone $C$-glucosides, vitexin and isoorientin. Their structures were elucidated by spectroscopic analyses.

Key words Glochidion zeylanicum; Euphorbiaceae; catechin; flavanol glucoside; glochiflavanoside A-D

Plants growing in Okinawa draw our attention, since regional cultures have developed independently from those on the mainland of Japan, accordingly regional medicinal plants and foodstuffs are still in use. ${ }^{1)}$ In continuing work on plants growing in Okinawa, the constituents of Glochidion zeylanicum were investigated, and glochidionolactones $\mathrm{A}-\mathrm{F}$, butenolide glycosides and lignans have been isolated. ${ }^{2)}$ In the present work, several flavanol glucosides named glochiflavanosides $\mathrm{A}-\mathrm{D}(\mathbf{3}-\mathbf{6})$ were isolated along with several known $C$-glucosyl flavones, vitexin (1) ${ }^{3)}$ and isoorientin (2). ${ }^{4)}$ This paper deals with the structural elucidation of these new compounds.

Glochiflavanoside $\mathrm{A}(3),[\alpha]_{\mathrm{D}}-47.1^{\circ}$, was isolated as an amorphous powder and its elemental composition was determined to be $\mathrm{C}_{23} \mathrm{H}_{28} \mathrm{O}_{11}$ from the observation of a quasi-molecular ion peak at $\mathrm{m} / z 479.1583$ on negative-ion high-resolution (HR) FAB mass spectrometry. The IR (1617, 1600, $\left.1520 \mathrm{~cm}^{-1}\right)$ and UV $(280 \mathrm{~nm})$ spectral absorption bands showed the presence of aromatic ring(s). The ${ }^{13} \mathrm{C}-\mathrm{NMR}$ spectrum showed the presence of six characteristic signals for a $\beta$-glucopyranose unit, and those attributable to two aromatic rings, one methylene $\left(\delta_{\mathrm{C}} 28.9\right)$, two secondary alcohols $\left(\delta_{\mathrm{C}}\right.$ 83.2, 68.6), and two methoxyls (Table 1). On acetylation with acetic anhydride and pyridine, a hexaacetyl derivative (3a) with one phenolic and five alcoholic acetyls was obtained. The ${ }^{1} \mathrm{H}-\mathrm{NMR}$ spectral data showed that one of the aromatic rings was tetrasubstituted with two meta-coupled protons and the other trisubstituted, whose protons coupled in an ABX system. From this evidence, the structure of $\mathbf{3}$ was presumed to be a derivative of catechin or epicatechin glucopyranoside. The coupling constant $(6 \mathrm{~Hz})$ between $\mathrm{H}-2$ and 3 favored these protons being in a catechin-type arrangement. The site of glucosylation was determined by nuclear<smiles>COc1cc([C@@H]2Oc3cc(O)cc(O)c3C[C@@H](O)[C@@H]2O)cc(O)c1O</smiles>
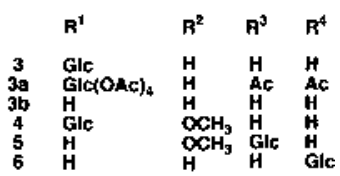

Fig. 1. Structures
Overhauser enhancement correlation spectroscopy (NOESY) (Fig. 2). The anomeric proton $\left(\delta_{\mathrm{H}} 4.61\right)$ crossed both of the meta-coupled aromatic protons $\left(\delta_{\mathrm{H}} 6.23,6.35\right)$, and the former aromatic proton crossed the methoxyl protons appearing at $\delta_{\mathrm{H}} 3.79$ on $\mathrm{C}-5\left(\delta_{\mathrm{C}} 160.0\right)$. The other methoxyl protons $\left(\delta_{\mathrm{H}} 3.83\right)$ crossed the meta-coupled aromatic proton $\left(\delta_{\mathrm{H}}\right.$ 6.96) on $\mathrm{C}-2^{\prime}$. In the heteronuclear multiple bond correlation (HMBC) spectrum, the methylene protons $\left(\delta_{\mathrm{H}} 2.52,2.89\right)$ showed cross peaks with C-5, H-6 with C-5, C-8 and C-10, H-8 with C-9 and then H-1" with C-7 (Fig. 2). Therefore, the planar structure of the aglycone was elucidated to be $3,7,4^{\prime}$-trihydroxy-5,3'-dimethoxyflavan and the sugar position was determined to be the hydroxyl group on C-7. The structure was further confirmed by the diagnostic NOESY and HMBC correlations shown in Fig. 2. Since enzymatic hydrolysis of 3 liberated D-glucose along with the aglycone (3b), and a negative Cotton peak $(\Delta \varepsilon-0.99)$ at $277 \mathrm{~nm}$ was observed in the circular dichroism (CD) spectrum, glochifla-

Table 1. ${ }^{13} \mathrm{C}-\mathrm{NMR}$ Data for Glochiflavanosides $\mathrm{A}-\mathrm{D}(\mathbf{3}-\mathbf{6})\left(\mathrm{CD}_{3} \mathrm{OD}\right.$ and/or $\left(\mathrm{CD}_{3}\right)_{2} \mathrm{SO}$ in Parentheses, $\left.100 \mathrm{MHz}\right)$

\begin{tabular}{crrrr}
\hline \hline Carbon No. & \multicolumn{1}{c}{$\mathbf{3}$} & $\mathbf{4}$ & $\mathbf{5}$ & \multicolumn{1}{c}{$\mathbf{6}$} \\
\hline 2 & 83.2 & $83.5(81.6)$ & $(81.1)$ & 80.5 \\
3 & 68.6 & $68.6(65.6)$ & $(65.8)$ & 75.6 \\
4 & 28.9 & $29.1(28.2)$ & $(28.3)$ & 26.7 \\
5 & 160.0 & $160.5(157.9)$ & $(158.0)$ & 160.2 \\
6 & 98.1 & $98.0(96.0)$ & $(94.9)$ & 96.4 \\
7 & 159.1 & $159.2(157.1)$ & $(156.8)$ & 158.4 \\
8 & 94.4 & $94.4(93.0)$ & $(91.8)$ & 93.0 \\
9 & 156.6 & $156.6(154.8)$ & $(154.8)$ & 156.4 \\
10 & 104.2 & $104.8(102.8)$ & $(102.6)$ & 103.6 \\
$1^{\prime}$ & 131.9 & $131.0(129.0)$ & $(134.4)$ & 132.0 \\
$2^{\prime}$ & 112.1 & $105.9(105.2)$ & $(105.9)$ & 112.0 \\
$3^{\prime}$ & 149.0 & $149.2(147.6)$ & $(152.2)$ & 149.0 \\
$4^{\prime}$ & 147.7 & $136.8(135.3)$ & $(134.8)$ & 147.6 \\
$5^{\prime}$ & 116.1 & $149.2(147.6)$ & $(152.2)$ & 116.2 \\
$6^{\prime}$ & 121.5 & $105.9(105.2)$ & $(105.9)$ & 120.8 \\
$1^{\prime \prime}$ & 102.6 & $102.6(100.6)$ & $(99.8)$ & 101.8 \\
$2^{\prime \prime}$ & 75.0 & $75.0(73.1)$ & $(74.1)$ & 75.2 \\
$3^{\prime \prime}$ & 78.2 & $78.3(76.9)$ & $(77.1)$ & 78.1 \\
$4^{\prime \prime}$ & 71.6 & $71.6(69.7)$ & $(69.8)$ & 71.7 \\
$5^{\prime}$ & 78.1 & $78.1(76.5)$ & $(76.4)$ & 77.9 \\
$6^{\prime}$ & 62.6 & $62.6(60.7)$ & $(60.8)$ & 62.9 \\
- OMe on 5 & 55.1 & $56.1(55.3)$ & $(55.1)$ & 56.0 \\
- OMe on 3' & 55.5 on 3', 5' $56.9(55.9)$ & $(55.3)$ & on 3' & 56.5 \\
\hline
\end{tabular}




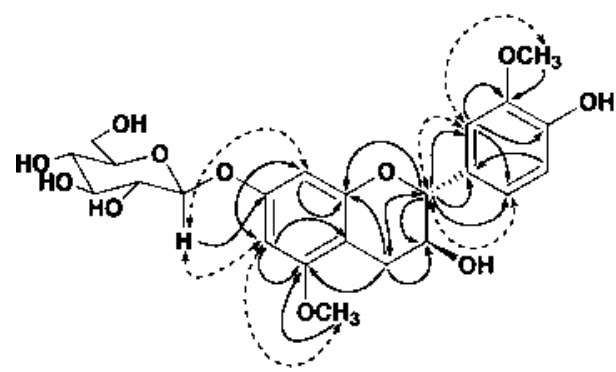

3

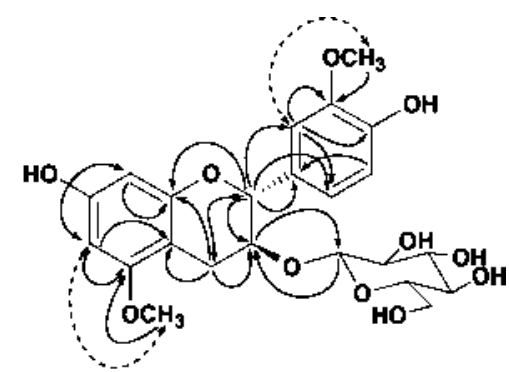

6

Fig. 2. Diagnostic HMBC and NOESY Correlations of 3 and 6

Solid lines denote the correlations observed in the HMBC experiment. The arrowheads indicate carbon atoms and the arrow tails proton atoms. Dotted lines denote the correlations observed in the NOESY experiment.

vanoside A (3) was finally characterized to be $(2 R, 3 S)$ $3,7,4^{\prime}$-trihydroxy-5,3' -dimethoxyflavan $7-O-\beta$-D-glucopyranoside.

Glochiflavanoside B (4) was isolated as colorless needles. The elemental composition $\left(\mathrm{C}_{24} \mathrm{H}_{30} \mathrm{O}_{12}\right)$ determined by negative-ion HR-FAB mass spectrometry $(\mathrm{m} / \mathrm{z} 509.1671)$ indicated that $\mathbf{4}$ had one more methoxyl group than $\mathbf{3}$. This was also evident in the NMR spectra. The NMR spectra showed that the chemical shift values of the $\mathrm{A}$ and $\mathrm{C}$ rings were essentially the same as those of $\mathbf{3}$, whereas the $\mathrm{B}$ ring had a symmetrical substitution. Based on this together with the results of CD spectrum $(\Delta \varepsilon-1.12$ at $277 \mathrm{~nm})$, the structure of 4 was elucidated to be $(2 R, 3 S)-3,7,4^{\prime}$-trihydroxy-5,3',5'trimethoxyflavan 7- $O-\beta$-D-glucopyranoside.

Glochiflavanoside C (5) was isolated as colorless needles and its elemental composition was found to be the same as that of 4. The NMR spectra showed that the B ring was symmetrically substituted, and the ${ }^{13} \mathrm{C}$-NMR chemical shifts of $\mathrm{C}-2,3$ and 4 in $\left(\mathrm{CD}_{3}\right) \mathrm{SO}$ were essentially the same as those of 4 in the same solvent (data in parentheses in Table 1). The ${ }^{13} \mathrm{C}-\mathrm{NMR}$ chemical shifts of the $\mathrm{A}$ and $\mathrm{B}$ rings were similar to those of 4 . However, those of C-6, 7 and 8 in the A ring, and those of $\mathrm{C}-3^{\prime}\left(=5^{\prime}\right)$ and $4^{\prime}$ in the $\mathrm{B}$ ring were significantly different, respectively. Therefore, the glucopyranosylation must occur at the $\mathrm{C}-4^{\prime}$ hydroxyl group and the structure of 5 was elucidated to be $(2 R, 3 S)-3,7,4^{\prime}$-trihydroxy-5, $3^{\prime}, 5^{\prime}$ trimethoxyflavan $4^{\prime}-O$ - $\beta$-D-glucopyranoside.

Glochiflavanoside D (6) was isolated as an amorphous powder and the elemental composition was found to be the same as that of 3 . The ${ }^{13} \mathrm{C}-\mathrm{NMR}$ chemical shifts of the $\mathrm{B}$ ring were essentially the same as those of $\mathbf{3}$, except for that of $\mathrm{C}$ $6^{\prime}$, and those of the A ring were significantly different from those of 3. A prominent difference was observed in the carbon at the 3-position ( $\delta_{\mathrm{C}} 68.6$ in 3, whereas 75.6 in $\mathbf{6}$ ). From this evidence, the $\beta$-glucopyranose moiety was presumed to be at the hydroxyl group at the 3-position. This was confirmed by the HMBC spectrum in which the anomeric proton $\left(\delta_{\mathrm{H}} 4.07\right)$ crossed the C-3 carbon $\left(\delta_{\mathrm{C}} 75.8\right)$, and the H-3 proton $\left(\delta_{\mathrm{H}} 4.28\right)$ the anomeric carbon $\left(\delta_{\mathrm{C}} 101.8\right)$. Other diagnostic correlations are shown in Fig. 2. Therefore, the structure of 6 was elucidated to be $(2 R, 3 S)-3,7,4^{\prime}$-trihydroxy-5, $3^{\prime}$ dimethoxyflavan 3- $O$ - $\beta$-D-glucopyranoside.

\section{Experimental}

General Procedure Melting points were determined with a Yanagimoto micro melting point apparatus and are uncorrected. Optical rotations were measured with a Union Giken PM-101 digital polarimeter. IR and UV spec- tra were recorded with Horiba FT-710 and Shimadzu UV-160A spectrophotometers. ${ }^{1} \mathrm{H}$ - and ${ }^{13} \mathrm{C}-\mathrm{NMR}$ spectra were taken with a JEOL $\alpha-400$ spectrometer $(400,100 \mathrm{MHz})$, with tetramethylsilane as an internal standard. HR-FAB-MS was carried out with a JEOL SX-102 mass spectrometer with PEG-400 as the calibration matrix. CD spectra were measured with a JASCO J-702 spectropolarimeter. Silica gel column chromatography and reversed-phase [octadecyl silica (ODS) gel] open column chromatography (RPCC) were performed on Silica gel 60 (Merck, 70-230 mesh) and Cosmosil $75 \mathrm{C}_{18}$-OPN (Nacalai Tesque, Kyoto) $[\Phi=50 \mathrm{~mm}, \mathrm{~L}=25 \mathrm{~cm}$, linear gradient: $\mathrm{MeOH}-\mathrm{H}_{2} \mathrm{O}(1: 9,11) \rightarrow(1: 1,11)$, fractions of $10 \mathrm{~g}$ being collected], respectively. The droplet counter-current chromatograph (DCCC) (Tokyo Rikakikai, Tokyo) was equipped with 500 glass columns ( $\Phi=2 \mathrm{~mm}$, $\mathrm{L}=40 \mathrm{~cm}$ ) and the lower and upper layers of the solvent, $\mathrm{CHCl}_{3}-\mathrm{MeOH}-$ $\mathrm{H}_{2} \mathrm{O}-n$-PrOH $(9: 12: 8: 2)$, were used as the stationary and mobile phases, respectively. Five gram fractions were collected and numbered according to the order of elution of the mobile phase. Preparative HPLC was performed on ODS [Inertsil, GL Science $(\Phi=2 \mathrm{~mm}, \mathrm{~L}=40 \mathrm{~cm})] .(2 R, 3 S)-(+)$-Catechin [ ${ }^{1} \mathrm{H}-\mathrm{NMR}\left(\mathrm{CD}_{3} \mathrm{OD}\right) \delta: 4.58(1 \mathrm{H}, \mathrm{d}, J=8 \mathrm{~Hz}, \mathrm{H}-2) ; \mathrm{CD}\left(c=8.76 \times 10^{-5} \mathrm{M}\right.$, $\mathrm{MeOH}) \Delta \varepsilon(\mathrm{nm})+0.20(245),-0.66(281)]$ and $(2 R, 3 R)-(-)$-epicatechin $\left[{ }^{1} \mathrm{H}-\mathrm{NMR}\left(\mathrm{CD}_{3} \mathrm{OD}\right) \delta: 4.82(1 \mathrm{H}, \mathrm{s}, \mathrm{H}-2)\right]$ were purchased from Sigma Co., Ltd. (St. Louis, MO, U.S.A.). Emulsin was also obtained from Sigma Co., Ltd. A Sep-Pak C18 cartridge was from Waters Assoc. Inc. (Milford, MA, U.S.A.).

Plant Material Leaves of G. zeylanicum were collected in Kunigami Village, Kunigami County, Okinawa, Japan, in August 1990. The plants were identified by Mr. Anki Takushi of the Okinawa Prefectural Station of Forestry, to whom the authors are very grateful, and a voucher specimen was deposited in the Herbarium of the Institute of Pharmaceutical Sciences, Hiroshima University School of Medicine (90-GZ-Okinawa-0822).

Extraction and Isolation Air-dried leaves $(4.72 \mathrm{~kg})$ of G. zeylanicum were extracted with $\mathrm{MeOH}$ three times. Parts of the extraction and isolation procedures were described in the previous paper. ${ }^{1)}$

The residue $(25.9 \mathrm{~g})$ of the $60 \% \mathrm{MeOH}$ (b) eluate obtained on Diaion HP20 column chromatography was subjected to silica gel $(500 \mathrm{~g})$ column chromatography with a stepwise increase in the $\mathrm{MeOH}$ content in $\mathrm{CHCl}_{3}$ $\left[\mathrm{CHCl}_{3}, 21\right.$, and $\mathrm{CHCl}_{3}-\mathrm{MeOH}, 31$ each of $49: 1,97: 3,24: 1,19: 1$, $92.5: 7.5,9: 1,7: 1,17: 3,82.5: 17.5,4: 1$ and $77.5: 22.5,500 \mathrm{ml}$ fractions were collected]. The residue $(855 \mathrm{mg})$ of $10 \% \mathrm{MeOH}$ eluate was then subjected to RPCC to give fractions $(100-110)$ enriched with glochiflavanosides A (3) and B (4). Glochiflavanoside B (4) was isolated as colorless crystals $(39 \mathrm{mg}$ ) and the mother liquid was purified by DCCC to give $40 \mathrm{mg}$ of glochiflavanoside A (3) and $9 \mathrm{mg}$ of 4 . The residue $(81 \mathrm{mg}$ in fractions 123 -129) obtained on RPCC was subjected to DCCC to give $25 \mathrm{mg}$ of glochiflavanoside C (5) as colorless crystals in fractions 55-68, and the residue $(8 \mathrm{mg})$ of fractions $48-54$ was purified by preparative HPLC $\left(\mathrm{H}_{2} \mathrm{O}-\mathrm{MeOH}, 7: 3\right)$ to afford $3.3 \mathrm{mg}$ of glochiflavanoside D (6). Further amounts of glochiflavanosides A $(25 \mathrm{mg})(3)$ and B $(16 \mathrm{mg})(4)$ were isolated from the residue $(3.92 \mathrm{~g})$ of $12.5-15 \% \mathrm{MeOH}$ eluate obtained on silica gel column chromatography.

Vitexin (52 mg) (1) and isoorientin (47 mg) (2) were isolated as yellow crystals from the residue of the $17.5-20 \% \mathrm{MeOH}$ eluate obtained on silica gel column chromatography by RPCC followed by DCCC separation.

Known Compounds Isolated Vitexin (1), yellow crystals, mp 205$210^{\circ} \mathrm{C},[\alpha]_{\mathrm{D}}^{25}+68.8^{\circ}(c=0.80$, pyridine $) .^{3)}$ Isoorientin (2), yellow crystals, $\mathrm{mp} 245-250^{\circ} \mathrm{C}(\mathrm{dec}),.[\alpha]_{\mathrm{D}}^{25} \mathrm{ca} .0^{\circ}(c=0.67$, pyridine $){ }^{4)}$

Glochiflavanoside A (3): Amorphous powder; $[\alpha]_{\mathrm{D}}^{22}-47.1^{\circ}(c=1.57$, 
$\mathrm{MeOH})$; IR (KBr) $v_{\max } 3397,2915,1617,1600,1520,1455,1274,1119$, $1073,1033,820 \mathrm{~cm}^{-1}$; UV (MeOH): $\lambda_{\max } 213$ (4.37), 227sh (4.21), 280 (3.62) nm $(\log \varepsilon) ;{ }^{1} \mathrm{H}-\mathrm{NMR}\left(\mathrm{CD}_{3} \mathrm{OD}\right) \delta: 2.52(1 \mathrm{H}, \mathrm{dd}, J=8,16 \mathrm{~Hz}, \mathrm{H}-4 \mathrm{a})$, $2.89(1 \mathrm{H}, \mathrm{dd}, J=6,16 \mathrm{~Hz}, \mathrm{H}-4 \mathrm{~b}), 3.67(1 \mathrm{H}, \mathrm{dd}, J=6,12 \mathrm{~Hz}, \mathrm{H}-6 " \mathrm{a}), 3.79$ $(3 \mathrm{H}, \mathrm{s},-\mathrm{OMe}$ on $\mathrm{C}-5), 3.83\left(3 \mathrm{H}, \mathrm{s},-\mathrm{OMe}\right.$ on $\left.\mathrm{C}-3^{\prime}\right), 3.88(1 \mathrm{H}, \mathrm{dd}, J=2$, $\left.12 \mathrm{~Hz}, \mathrm{H}-6^{\prime \prime} \mathrm{b}\right), 4.00(1 \mathrm{H}, \mathrm{dt}, J=6,8 \mathrm{~Hz}, \mathrm{H}-3), 4.61\left(1 \mathrm{H}, \mathrm{d}, J=8 \mathrm{~Hz}, \mathrm{H}-1^{\prime \prime}\right)$, $4.84(1 \mathrm{H}, \mathrm{d}, J=8 \mathrm{~Hz}, \mathrm{H}-2), 6.28(1 \mathrm{H}, \mathrm{d}, J=2 \mathrm{~Hz}, \mathrm{H}-6), 6.35(1 \mathrm{H}, \mathrm{d}, J=2 \mathrm{~Hz}$, $\mathrm{H}-8), 6.79\left(1 \mathrm{H}, \mathrm{d}, J=8 \mathrm{~Hz}, \mathrm{H}-5^{\prime}\right), 6.84\left(1 \mathrm{H}, \mathrm{dd}, J=2,8 \mathrm{~Hz}, \mathrm{H}-6^{\prime}\right), 6.96(1 \mathrm{H}$, d, $\left.J=2 \mathrm{~Hz}, \mathrm{H}-2^{\prime}\right) ;{ }^{13} \mathrm{C}-\mathrm{NMR}\left(\mathrm{CD}_{3} \mathrm{OD}\right)$ : see Table 1; CD $\Delta \varepsilon(\mathrm{nm}):-3.40$ (234), -0.99 (277) $\left(c=8.19 \times 10^{-5} \mathrm{M}, \mathrm{MeOH}\right)$; HR-FAB-MS (negative-ion mode) $m / z: 479.1583[\mathrm{M}-\mathrm{H}]^{-}$(Calcd for $\left.\mathrm{C}_{23} \mathrm{H}_{27} \mathrm{O}_{11}: 479.1553\right)$.

Glochiflavanoside B (4): Colorless needles $(\mathrm{MeOH}) ; \mathrm{mp} 222-224^{\circ} \mathrm{C}$; $[\alpha]_{\mathrm{D}}^{22}-61.4^{\circ}(c=0.57, \mathrm{MeOH}) ; \mathrm{IR}(\mathrm{KBr}) v_{\max } 3326,2944,1619,1598$, $1525,1498,1455,1217,1166,1121,1073,837 \mathrm{~cm}^{-1}$; UV (MeOH) $\lambda_{\max }$ 226sh (4.24), $271(3.28) \mathrm{nm}(\log \varepsilon) ;{ }^{1} \mathrm{H}-\mathrm{NMR}\left(\mathrm{CD}_{3} \mathrm{OD}\right) \delta: 2.53(1 \mathrm{H}, \mathrm{dd}$, $J=9,16 \mathrm{~Hz}, \mathrm{H}-4 \mathrm{a}), 2.90(1 \mathrm{H}, \mathrm{dd}, J=6,16 \mathrm{~Hz}, \mathrm{H}-4 \mathrm{~b}), 3.67(1 \mathrm{H}, \mathrm{dd}, J=6$, $\left.12 \mathrm{~Hz}, \mathrm{H}-6^{\prime \prime} \mathrm{a}\right), 3.79$ ( $3 \mathrm{H}, \mathrm{s},-\mathrm{OMe}$ on C-5), 3.83 (6H, s, $-\mathrm{OMe}$ on C-3', $5^{\prime}$ ), $3.88\left(1 \mathrm{H}, \mathrm{dd}, J=2,12 \mathrm{~Hz}, \mathrm{H}-6^{\prime \prime} \mathrm{b}\right), 4.01(1 \mathrm{H}, \mathrm{dt}, J=6,9 \mathrm{~Hz}, \mathrm{H}-3), 4.60(1 \mathrm{H}$, d, $\left.J=8 \mathrm{~Hz}, \mathrm{H}-1^{\prime \prime}\right), 6.29(1 \mathrm{H}, \mathrm{d}, J=2 \mathrm{~Hz}, \mathrm{H}-6), 6.37(1 \mathrm{H}, \mathrm{d}, J=2 \mathrm{~Hz}, \mathrm{H}-8)$, $6.68\left(2 \mathrm{H}, \mathrm{s}, \mathrm{H}_{2}-2^{\prime}, 6^{\prime}\right) ;{ }^{13} \mathrm{C}$-NMR $\left[\mathrm{CD}_{3} \mathrm{OD},\left(\mathrm{CD}_{3}\right)_{2} \mathrm{SO}\right]$ : see Table $1 ; \mathrm{CD} \Delta \varepsilon$ (nm): $(\mathrm{MeOH})-4.70(236),-1.12(277)\left(c=5.58 \times 10^{-5} \mathrm{M}, \mathrm{MeOH}\right) ; \mathrm{HR}-$ FAB-MS (negative-ion mode) $m / z: 509.1671[\mathrm{M}-\mathrm{H}]^{-}\left(\right.$Calcd for $\mathrm{C}_{24} \mathrm{H}_{29} \mathrm{O}_{12}$ : 509.1659)

Glochiflavanoside C (5): Colorless needles $(\mathrm{MeOH}) ; \mathrm{mp} 260-262^{\circ} \mathrm{C}$; $[\alpha]_{\mathrm{D}}^{25}-5.7^{\circ}(c=0.35$, pyridine $)$, IR $(\mathrm{KBr}) v_{\max } 3400,2923,1622,1601$, $1505,1467,1428,1244,1146,1122,1069,1012,981,820 \mathrm{~cm}^{-1}$; UV (MeOH) $\lambda_{\max } 212$ (4.63), 228sh (4.26), 271 (3.27) nm (log $\varepsilon$ ); ${ }^{1} \mathrm{H}-\mathrm{NMR}$ (DMSO- $\left.d_{6}\right)$ d: $2.39(1 \mathrm{H}, \mathrm{dd}, J=9,16 \mathrm{~Hz}, \mathrm{H}-4 \mathrm{a}), 2.76(1 \mathrm{H}, \mathrm{dd}, J=6,16 \mathrm{~Hz}$, $\mathrm{H}-4 \mathrm{~b}), 3.70(3 \mathrm{H}, \mathrm{s},-\mathrm{OMe}$ on $\mathrm{C}-5), 3.75\left(6 \mathrm{H}, \mathrm{s},-\mathrm{OMe}\right.$ on $\left.\mathrm{C}-3^{\prime}, 5^{\prime}\right), 3.95$ $(1 \mathrm{H}, \mathrm{td}, J=6,9 \mathrm{~Hz}, \mathrm{H}-3), 4.56\left(1 \mathrm{H}, \mathrm{d}, J=8 \mathrm{~Hz}, \mathrm{H}-1^{\prime \prime}\right), 5.01(1 \mathrm{H}, \mathrm{d}, J=6 \mathrm{~Hz}$, $\mathrm{H}-2), 5.87(1 \mathrm{H}, \mathrm{d}, J=2 \mathrm{~Hz}, \mathrm{H}-6), 5.99(1 \mathrm{H}, \mathrm{d}, J=2 \mathrm{~Hz}, \mathrm{H}-8), 6.69\left(2 \mathrm{H}, \mathrm{s}, \mathrm{H}_{2}-\right.$ $\left.2^{\prime}, 6^{\prime}\right) ;{ }^{13} \mathrm{C}$-NMR $\left(\left(\mathrm{CD}_{3}\right) \mathrm{SO}\right)$ : see Table 1; CD $\Delta \varepsilon(\mathrm{nm}):-2.41(232),+0.64$ (247), $-0.53(280)\left(c=4.20 \times 10^{-5} \mathrm{M}, \mathrm{MeOH}\right)$; HR-FAB-MS (negative-ion mode) $m / z: 509.1688[\mathrm{M}-\mathrm{H}]^{-}$(Calcd for $\mathrm{C}_{24} \mathrm{H}_{29} \mathrm{O}_{12}: 509.1659$ ).

Glochiflavanoside D (6): Amorphous powder; UV (MeOH) $\lambda_{\max } 229 \mathrm{sh}$ (4.12), $280(3.56) \mathrm{nm}(\log \varepsilon) ;{ }^{1} \mathrm{H}-\mathrm{NMR}(\mathrm{MeOH}) \delta: 2.69(1 \mathrm{H}, \mathrm{dd}, J=7$, $17 \mathrm{~Hz}, \mathrm{H}-4 \mathrm{a}), 2.78(1 \mathrm{H}, \mathrm{dd}, J=5,17 \mathrm{~Hz}, \mathrm{H}-4 \mathrm{~b}), 3.10(1 \mathrm{H}, \mathrm{dd}, J=8,9 \mathrm{~Hz}, \mathrm{H}-$ $\left.2^{\prime \prime}\right), 3.14\left(1 \mathrm{H}, \mathrm{ddd}, J=2,6,9 \mathrm{~Hz}, \mathrm{H}-5^{\prime \prime}\right), 3.20\left(1 \mathrm{H}, \mathrm{t}, J=9 \mathrm{~Hz}, \mathrm{H}-4^{\prime \prime}\right), 3.22$ $\left(1 \mathrm{H}, \mathrm{t}, J=9 \mathrm{~Hz}, \mathrm{H}-3^{\prime \prime}\right), 3.65\left(1 \mathrm{H}, \mathrm{dd}, J=6,12 \mathrm{~Hz}, \mathrm{H}-6^{\prime \prime} \mathrm{a}\right), 3.75(3 \mathrm{H}, \mathrm{s},-\mathrm{OMe}$ on $\mathrm{C}-5), 3.82\left(3 \mathrm{H}, \mathrm{s},-\mathrm{OMe}\right.$ on $\left.\mathrm{C}-3^{\prime}\right), 3.84\left(1 \mathrm{H}, \mathrm{dd}, J=2,12 \mathrm{~Hz}, \mathrm{H}-6^{\prime \prime} \mathrm{b}\right)$, $4.07\left(1 \mathrm{H}, \mathrm{d}, J=8 \mathrm{~Hz}, \mathrm{H}-1^{\prime \prime}\right), 4.28(1 \mathrm{H}, \mathrm{dt}, J=5,7 \mathrm{~Hz}, \mathrm{H}-3), 4.92(1 \mathrm{H}, \mathrm{d}$, $J=7 \mathrm{~Hz}, \mathrm{H}-2), 5.98(1 \mathrm{H}, \mathrm{d}, J=2 \mathrm{~Hz}, \mathrm{H}-6), 6.04(1 \mathrm{H}, \mathrm{d}, J=2 \mathrm{~Hz}, \mathrm{H}-8), 6.78$ $\left(1 \mathrm{H}, \mathrm{d}, J=8 \mathrm{~Hz}, \mathrm{H}-5^{\prime}\right), 6.84\left(1 \mathrm{H}, \mathrm{dd}, J=2,8 \mathrm{~Hz}, \mathrm{H}-6^{\prime}\right), 6.97(1 \mathrm{H}, \mathrm{d}, J=2 \mathrm{~Hz}$, H-2'); ${ }^{13} \mathrm{C}-\mathrm{NMR}(\mathrm{MeOH})$ : see Table 1 ; CD $\Delta \varepsilon(\mathrm{nm}):-0.90(232),+0.25$ (246), -0.53 (281) $\left(c=5.52 \times 10^{-5} \mathrm{M}, \mathrm{MeOH}\right)$; HR-FAB-MS (negative-ion mode) $m / z: 479.1550[\mathrm{M}-\mathrm{H}]^{-}\left(\right.$Calcd for $\left.\mathrm{C}_{23} \mathrm{H}_{27} \mathrm{O}_{11}: 479.1553\right)$.

Acetylation of Glochiflavanoside A Glochiflavanoside A (3, $5.0 \mathrm{mg})$ was acetylated with $200 \mu \mathrm{l}$ each of acetic anhydride and pyridine at $25^{\circ} \mathrm{C}$ for $4 \mathrm{~h}$. A usual workup gave $6.2 \mathrm{mg}(82 \%)$ of the hexaacetate (3a). Hexaacetate, amorphous powder, ${ }^{1} \mathrm{H}-\mathrm{NMR}\left(\mathrm{CDCl}_{3}\right) \delta: 1.97(3 \mathrm{H}, \mathrm{s}), 2.01(3 \mathrm{H}, \mathrm{s})$, $2.03(3 \mathrm{H}, \mathrm{s}), 2.04(3 \mathrm{H}, \mathrm{s}), 2.07(3 \mathrm{H}, \mathrm{s})\left(-\mathrm{OCOCH}_{3} \times 5\right.$ on alcoholic $\left.-\mathrm{OH}\right)$, $2.29(3 \mathrm{H}, \mathrm{s})\left(-\mathrm{OCOCH}_{3}\right.$ on phenolic $\left.-\mathrm{OH}\right), 2.69(1 \mathrm{H}, \mathrm{dd}, J=6,17 \mathrm{~Hz}, \mathrm{H}-$ 4a), $2.87(1 \mathrm{H}, \mathrm{dd}, J=5,17 \mathrm{~Hz}, \mathrm{H}-4 \mathrm{~b}), 3.85\left(1 \mathrm{H}, \mathrm{ddd}, J=3,6,10 \mathrm{~Hz}, \mathrm{H}-5^{\prime \prime}\right)$, 4.17 (1H, dd, $J=3,12 \mathrm{~Hz}, \mathrm{H}-6 " \mathrm{a}), 4.26$ (1H, dd, $J=6,12 \mathrm{~Hz}, \mathrm{H}-6 " \mathrm{~b}), 5.06$
$(1 \mathrm{H}, \mathrm{d}, J=6 \mathrm{~Hz}, \mathrm{H}-2), 5.08\left(1 \mathrm{H}, \mathrm{d}, J=8 \mathrm{~Hz}, \mathrm{H}-1^{\prime \prime}\right), 5.14(1 \mathrm{H}, \mathrm{dd}, J=9,10 \mathrm{~Hz}$, H-4"), $5.25\left(1 \mathrm{H}, \mathrm{dd}, J=8,9 \mathrm{~Hz}, \mathrm{H}-2^{\prime \prime}\right), 5.30\left(1 \mathrm{H}, \mathrm{t}, J=9 \mathrm{~Hz}, \mathrm{H}-3^{\prime \prime}\right), 5.34(1 \mathrm{H}$, dt, $J=5,6 \mathrm{~Hz}, \mathrm{H}-3), 6.17(1 \mathrm{H}, \mathrm{d}, J=2 \mathrm{~Hz}, \mathrm{H}-6), 6.25(1 \mathrm{H}, \mathrm{d}, J=2 \mathrm{~Hz}, \mathrm{H}-8)$, $6.90\left(1 \mathrm{H}, \mathrm{dd}, J=2,8 \mathrm{~Hz}, \mathrm{H}-6^{\prime}\right), 6.95\left(1 \mathrm{H}, \mathrm{d}, J=2 \mathrm{~Hz}, \mathrm{H}-2^{\prime}\right), 7.00(1 \mathrm{H}, \mathrm{d}$, $\left.J=8 \mathrm{~Hz}, \mathrm{H}-5^{\prime}\right) ;{ }^{13} \mathrm{C}-\mathrm{NMR}\left(\mathrm{CDCl}_{3}\right) \delta: 22.57(\times 2), 22.59,22.63,22.68,21.02$ $\left(-\mathrm{OCOCH}_{3} \times 6\right), 23.7(\mathrm{C}-4), 55.6,56.3\left(-\mathrm{OCH}_{3} \times 2\right), 62.0\left(\mathrm{C}-6^{\prime \prime}\right), 68.5,68.9$ (C-3, 4"), 71.3, 72.2, $72.9\left(\mathrm{C}-2^{\prime \prime}, 3^{\prime \prime}, 5^{\prime \prime}\right), 78.2(\mathrm{C}-2), 94.1$ (C-8), 96.5 (C-6), $98.9\left(\mathrm{C}-1^{\prime \prime}\right), 103.5$ (C-10), 110.7 (C-2'), $119.0\left(\mathrm{C}-5^{\prime}\right), 122.8$ (C-6'), 136.6 (C-1'), 139.8 (C-4'), 151.3 (C-3'), 154.6 (C-9), 156.9 (C-7), 158.7 (C-5), $168.77,169.34,169.41,170.14,170.19,170.57\left(-\mathrm{OCOCH}_{3} \times 6\right)$; HR-FABMS (positive-ion mode, $m$-nitrobenzyl alcohol as a matrix) $\mathrm{m} / \mathrm{z}$ : 755.2175 $[\mathrm{M}+\mathrm{Na}]^{+}(+\mathrm{NaI})\left(\mathrm{Calcd}\right.$ for $\mathrm{C}_{35} \mathrm{H}_{40} \mathrm{O}_{17} \mathrm{Na}$ : 755.2163).

Enzymatic Hydrolysis of Glochiflavanoside A to Its Aglycone (3b) and D-Glucose Glochiflavanoside A $(3,17.0 \mathrm{mg})$ was hydrolyzed with $9 \mathrm{mg}$ of emulsin in $2 \mathrm{ml}$ of $\mathrm{H}_{2} \mathrm{O}$ at $37^{\circ} \mathrm{C}$ for $5 \mathrm{~h}$. The precipitate formed was collected by suction. The precipitate was dissolved in $\mathrm{MeOH}$ and the insoluble material was removed by filtration. The filtrate was evaporated and crystallized from $\mathrm{MeOH}$ to give $9.6 \mathrm{mg}(87 \%)$ of the aglycone $(\mathbf{3 b})$ as colorless needles.

The filtrate was concentrated and the residue was triturated with $\mathrm{MeOH}$. The denatured enzyme was filtered off and the filtrate was evaporated to dryness. The residue was again dissolved in $\mathrm{H}_{2} \mathrm{O}$ and the resulting solution was passed through a Sep-Pak $\mathrm{C}_{18}$ cartridge to give $5.0 \mathrm{mg}$ (79\%) of glucose in the $\mathrm{H}_{2} \mathrm{O}$ eluate.

Aglycone (3b): Colorless needles $(\mathrm{MeOH}), \mathrm{mp} 184-186^{\circ} \mathrm{C},[\alpha]_{\mathrm{D}}^{25}-5.8^{\circ}$ $(c=0.68, \mathrm{MeOH}) ;{ }^{1} \mathrm{H}-\mathrm{NMR}\left(\mathrm{CD}_{3} \mathrm{OD}\right) \delta: 2.50(1 \mathrm{H}, \mathrm{dd}, J=8,16 \mathrm{~Hz}, \mathrm{H}-4 \mathrm{a})$, $2.86(1 \mathrm{H}, \mathrm{dd}, J=5,16 \mathrm{~Hz}, \mathrm{H}-4 \mathrm{~b}), 3.76,3.84$ (each $3 \mathrm{H}$, each $\left.\mathrm{s},-\mathrm{OCH}_{3} \times 2\right)$, $4.00(1 \mathrm{H}, \mathrm{dt}, J=5,8 \mathrm{~Hz}, \mathrm{H}-3), 4.60(1 \mathrm{H}, \mathrm{d}, J=8 \mathrm{~Hz}, \mathrm{H}-2), 5.95(1 \mathrm{H}, \mathrm{d}$, $J=2 \mathrm{~Hz}, \mathrm{H}-6), 6.03(1 \mathrm{H}, \mathrm{d}, J=2 \mathrm{~Hz}, \mathrm{H}-8), 6.79\left(1 \mathrm{H}, \mathrm{d}, J=8 \mathrm{~Hz}, \mathrm{H}-5^{\prime}\right), 6.84$ $\left(1 \mathrm{H}, \mathrm{dd}, J=2,8 \mathrm{~Hz}, \mathrm{H}-66^{\prime}\right), 6.96\left(1 \mathrm{H}, \mathrm{d}, J=2 \mathrm{~Hz}, \mathrm{H}-2^{\prime}\right) ;{ }^{13} \mathrm{C}-\mathrm{NMR}\left(\mathrm{CD}_{3} \mathrm{OD}\right)$ $\delta: 28.8(\mathrm{C}-4), 55.9,56.5\left(-\mathrm{OCH}_{3} \times 2\right), 68.8(\mathrm{C}-3), 83.1(\mathrm{C}-2), 92.9(\mathrm{C}-8)$, 96.5 (C-6), 101.9 (C-10), $112.1\left(\mathrm{C}-2^{\prime}\right), 116.1\left(\mathrm{C}-5^{\prime}\right), 121.4\left(\mathrm{C}-6^{\prime}\right), 132.1$ (C1'), 147.6 (C-4'), 149.0 (C-3'), 156.8 (C-9), 158.3 (C-7), 160.2 (C-5); HRFAB-MS (negative-ion mode) $\mathrm{m} / z: 317.0998[\mathrm{M}-\mathrm{H}]^{-}$(Calcd for $\mathrm{C}_{17} \mathrm{H}_{17} \mathrm{O}_{6}$ : 317.1025. D-Glucose: $[\alpha]_{\mathrm{D}}^{25}+36.0^{\circ}\left(c=0.33, \mathrm{H}_{2} \mathrm{O}, 24 \mathrm{~h}\right.$ after being dissolved in the solvent).

Acknowledgements The authors are grateful for access to the superconducting NMR instrument at the Analytical Center of Molecular Medicine of Hiroshima University Faculty of Medicine. Thanks are also due to the Okinawa Foundation for the financial support through an Okinawa Research Promotion Award (H.O.).

\section{References}

1) a) Nakata F., Nakata K., "Medicinal Plants," Shinsei Press Ltd., Naha, Okinawa, 1991; b) Tawada S., Ohta F., "Encyclopedia of Medicinal Plants in Okinawa," Shinsei Press Ltd., Naha, Okinawa, 1985.

2) a) Otsuka H., Hirata E., Takushi A., Shinzato T., Takeda Y., Bando M., Kido M., Chem. Pharm. Bull., 48, 547-551 (2000); b) Otsuka H., Hirata E., Shinzato T., Takeda Y., ibid., 48, 1084-1086 (2000).

3) Morita N., Arisawa M., Yoshikawa A., Yakugaku Zasshi, 96, 11801183 (1976)

4) Komatsu M., Tomimori T., Makiguchi Y., Chem. Pharm. Bull., 15, 1567-1572 (1967). 